\title{
IN VITRO ANTIMICROBIAL ACTIVITY OF SOME ESSENTIAL OILS AGAINST BACTERIAL PATHOGENS CAUSING SKIN DISEASES IN VAPOR PHASE
}

\author{
PURIT PATTANAPANIT, SUNISA MITHONGLANG, SUNITA MITHONGLANG, SURACHAI TECHAOEI* \\ Thai Traditional Medicine College, Rajamangala University of Technology Thanyaburi, Pathum Thani, Thailand. \\ Email: surachai_te@rmutt.ac.th
}

Received: 26 December 2018, Revised 29 December 2018 and Accepted: 16 February 2019

\section{ABSTRACT}

Objective: The objective of this study was to evaluate the antimicrobial activity of volatile oils from aromatic plants against pathogenic bacteria.

Methods: Thai aromatic plants such as Pogostemon cablin (Blanco) Benth (Patchouli oil), Cymbopogon nardus Rendle (Citronella grass oil), Pelargonium roseum (Geranium oil), Syzygium aromaticum (L.) Merrill and Perry (clove oil), Cinnamomum spp.(cinnamon oil), and Cymbopogon citratus (DC.) Stapf. (lemongrass oil) were selected. Essential oils were obtained by water distillation and were stored at $4^{\circ} \mathrm{C}$ until use. Five human pathogenic bacteria were obtained from Thai traditional Medicine College, Rajamangala University of Technology, Staphylococcus epidermidis, Escherichia coli, Staphylococcus aureus, methicillin-resistant S. aureus (MRSA), and Pseudomonas aeruginosa. The antibacterial activity of volatile oils was determined by disc-diffusion assay. Minimum inhibitory concentration (MIC) and minimum bactericidal concentration (MBC) of each essential oil were determined.

Results: Our study showed that $10 \%$ of essential oil from Cinnamomum spp. was the most potential against S. aureus, MRSA, and E. coli when assayed by disc-diffusion method with inhibition zones ranging from $37.66 \pm 0.57$ to $45.33 \pm 1.15 \mathrm{~mm}$ and from $29.33 \pm 0.57$ to $36.00 \pm 1.00$ for lemongrass oil with MIC and MBC of $1.25 \%$.

Conclusion: From this study, it can be concluded that some essential oils have potential antibacterial activity. The present investigation provides support to the antibacterial properties of essential oils and will be applied to health-care product as aroma antibacterial products.

Keywords: Antibacterial activity, Skin diseases, Volatile oils, Pathogen.

(C) 2019 The Authors. Published by Innovare Academic Sciences Pvt Ltd. This is an open access article under the CC BY license (http://creativecommons. org/licenses/by/4. 0/) DOI: http://dx.doi.org/10.22159/ijap.2019.v11s5.T0084

\section{INTRODUCTION}

Skin infectious disease is a disorder of exclusively the superficial layers of the skin, infected by organisms such as bacteria, viruses, fungi, and parasites [1]. The pathogens including Staphylococcus aureus, Escherichia coli, Pseudomonas aeruginosa, Bacillus subtilis, and drugresistant bacteria caused several skin human infections [2-8]. Thus, the global prevalence of infectious disease caused by bacteria is a major public health problem [9]. However, it is important to note that the effects of synthetic drugs can be highly unpredictable, making difficult to fully assess their physical impact. Hence, the natural compounds or essential oils from medicinal plant have an alternative to treat the antimicrobial agent. Medicinal plants have been used as primary treatment of skin disorders for centuries in Thailand Traditional Medicine, Chinese Traditional Medicine, and Indian Traditional Medicine.

Essential oils of medicinal plants present a great potential of application as natural antimicrobial agents [9]. They are mixtures of natural volatile molecule deriving from plant secondary metabolism which potent antibacterial, antifungal, antiviral, insecticidal and antioxidant activities. Generally, the biological activity of essential oil depends on their chemical structure, environmental, and agronomic conditions [10]. Thus, the objective of this research was to screen the antibacterial activity of volatile oil from medicinal plants in Thailand against skin human pathogenic bacteria.

\section{METHODS}

The extraction of essential oils from medicinal plants Pogostemon cablin (Blanco) Benth (Patchouli oil), Cymbopogon nardus Rendle (Citronella grass oil), Pelargonium roseum (Geranium oil), Syzygium aromaticum (L.) Merrill and Perry (clove oil), Cinnamomum spp.(cinnamon oil), and Cymbopogon citratus (DC.)
Stapf. (lemongrass oil) were selected. Briefly, the medicinal plant was completely immersed in water and heated to boiling, after which the essential oil was evaporated together with water vapor and finally collected after decantation. The distillate was isolated and dried in a Rotavapor to giving greenish-yellow oil. The oil was stored at $4^{\circ} \mathrm{C}$ until the antimicrobial screening [11].

\section{Antibacterial activity of the essential oils} Microorganisms

Antimicrobial activity determination was carried out against bacterial pathogens causing skin diseases, Staphylococcus epidermis, E. coli, methicillin-resistant $S$. aureus (MRSA), S. aureus, and P. aeruginosa.

Culture media

Bacteria were assayed on nutrient agar (NA) (Merck, g/L):peptone from meat, 50.0; meat extract, 3.0; agar, 12.0; and water, $1.0 \mathrm{~L}$.

Inocula

Inocula for the assays were prepared by incubation at $37^{\circ} \mathrm{C}$ for $18 \mathrm{~h}$ before use and were adjusted to McFarland scale of 0.5. Cell suspensions were finally diluted to $10^{4} \mathrm{cfu} / \mathrm{ml}$ for being used in the activity assay.

Disc volatilization assay

This assay requires a culture agar plate inoculated with microbial suspension adjusted by McFarland No. 0.5 containing $10^{6} \mathrm{cfu} / \mathrm{ml}$ inserted down on top of a container (Fig. 1). A paper disc ( $6 \mathrm{~mm}$ ) is deposited at the bottom of the container with $15 \mu$ of essential oils. All plates inoculated and the disc should be sealed with parafilm to prevent the steam outlet and incubated at $37 \mathrm{C}$ for $24 \mathrm{~h}$, and the inhibition zone was measured in millilitre (mm) [12]. The experiments were done by tree replicates (Fig. 1). 
Determination of minimum inhibitory concentration (MIC) and minimum bactericidal concentration (MBC)

To assess the MIC and MBC of essential oils, the serial two-flow dilution was carried out with the disc-diffusion assay. The MIC represented the lowest concentration showing an inhibition zone; the MBC was determined by subculturing which showed no bacterial growth on the agar plates after incubated at $37^{\circ} \mathrm{C}$ for $24 \mathrm{~h}$ in an incubator. The lowest concentration that did not show bacterial growth was defined

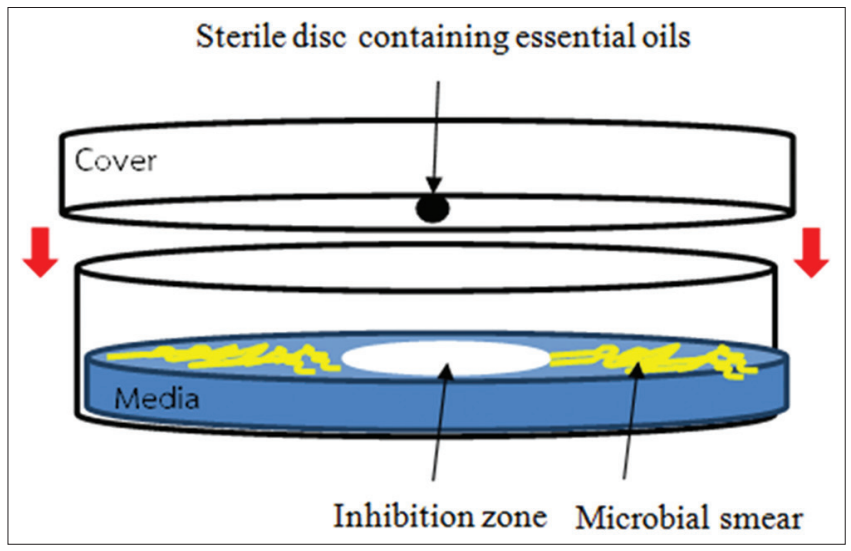

Fig. 1: Disc volatilization assay

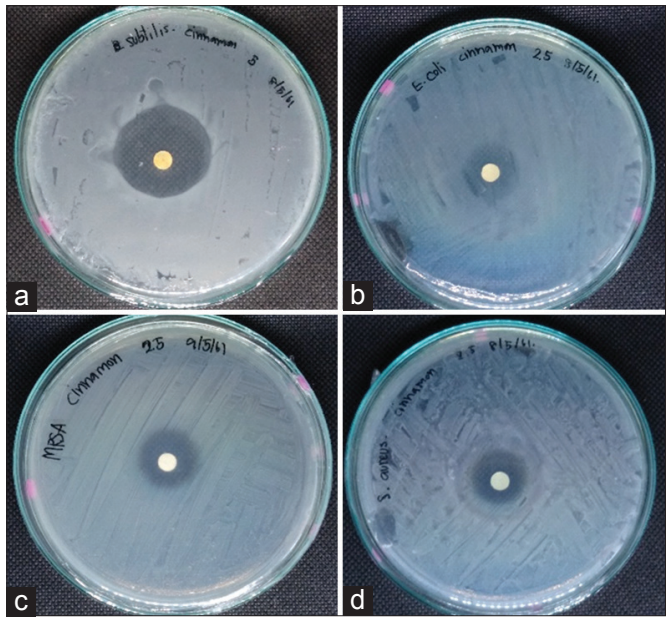

Fig. 2: The effect of cinnamon oil against skin pathogens (a) Bacillus subtilis $(5 \mathrm{mg} / \mathrm{ml})$, (b) Escherichia coli $(2.5 \mathrm{mg} / \mathrm{ml})$, (c) Staphylococcus aureus (methicillin-resistant $S$. aureus) $(2.5 \mathrm{mg} / \mathrm{ml})$, S. aureus $(2.5 \mathrm{mg} / \mathrm{ml})$, (d) S. aureus $(2.5 \mathrm{mg} / \mathrm{ml})$ as an $\mathrm{MBC}$ value. The experiment was conducted in triplicate, and the mean diameter of the zone of inhibition was recorded in millimeters $(\mathrm{mm})$. Erythromycin was used as a positive control, and dimethyl sulfoxide (DMSO) solution was used as a negative one. All experiments were performed in triplicate. The results were represented by mean \pm standard deviation (SD) $[13,14]$

\section{Statistical analysis}

The results of the data experiments were expressed in mean \pm SD for groups $(n=3)$

\section{RESULTS AND DISCUSSION}

Antibacterial activity of essential oils

Due to the absence of direct contact between the skin pathogenic bacteria and essential oils, the common skin pathogenic bacteria are listed in Table 1. The MIC was determined only for oils that presented positive on disc-diffusion assay. The results show a variable effect of essential oils on the bacterial pathogens. The essential oils from Cinnamomum spp. was great potential against MRSA, showing the lowest MIC values of $1.25 \%$ with clearing zone of $45.33 \pm 1.15 \mathrm{~mm}$ and MBC value of $1.25 \%$. As it can be appeared in Table 1, the essential oil of cinnamon oil exhibited the growth of $E$. coli and S. aureus with MIC and MBC value of $1.25 \%$ and showed zone of inhibition of $20.00 \pm 0.00$ and $37.66 \pm 0.57 \mathrm{~mm}$, respectively. The essential oil with the lowest MIC and MBC was that of clove, with MIC and MBC of $5.0 \%$ against $P$. aeruginosa with halo zone of $44.33 \pm 1.15 \mathrm{~mm}$ (Table 2). The MIC and MBC of clove oil at a concentration of $1.25 \%$ showed an inhibition zone of $33.66 \pm 1.52 \mathrm{~mm}$ with $B$. subtilis. However, as the same condition, it did not inhibit the growth of E. coli, S. aureus (MRSA) and S. aureus. The MIC and MBC of lemongrass oils at a concentration of $2.50 \%$ displayed the lowest concentration to inhibit the growth of MRSA, $S$. aureus, and B. subtilis with clearing zone of $36.00 \pm 1.00,36.00 \pm 1.00$ and $28.33 \pm 1.52 \mathrm{~mm}$ (Fig. 2). It also no antibacterial activity was observed in the controls as well as in the assays where only DMSO was used. Above $5.0 \%$, patchouli oil, citronella oil, and geranium oil did not show any antibacterial effective against $E$. coli, $S$. aureus (MRSA), S. aureus, and $P$. aeruginosa. In contrary, the citronella oil showed potent inhibition against pathogens [13]. The vaporization of the inhibition zone of cinnamon oil was observed on NA with the difference various skin pathogens and concentration of essential oils. This result was similar of the previous reported, concerning the antioxidant and the antimicrobial activity [15-20], indicating that the different plants species have a variety of different kinds of molecules. Hence, differences in the composition of essential oils, in the interactions of their constituents, and in their extraction and purification operations affect their antimicrobial activity [21].

\section{ACKNOWLEDGMENT}

The authors extend their appreciation to the Thai Traditional Medicine College, RMUTT, for all facilities and financial supported.

Table 1: The minimum inhibitory concentration of essential oils against skin pathogens

\begin{tabular}{|c|c|c|c|c|c|c|c|c|c|c|}
\hline \multirow[t]{3}{*}{ Essential oils } & \multicolumn{10}{|c|}{ Microorganisms } \\
\hline & \multicolumn{2}{|c|}{ Escherichia coli } & \multicolumn{2}{|c|}{ MRSA } & \multicolumn{2}{|c|}{ Staphylococcus aureus } & \multicolumn{2}{|c|}{$\begin{array}{l}\text { Pseudomonas } \\
\text { aeruginosa }\end{array}$} & \multicolumn{2}{|c|}{ Bacillus subtilis } \\
\hline & MIC $^{a}$ & Clear zone $^{\mathrm{b}}$ & MIC $^{\mathrm{a}}$ & Clear zone $^{\mathrm{b}}$ & MIC $^{a}$ & Clear zone $^{b}$ & MIC $^{\mathbf{a}}$ & Clear zone $^{\mathrm{b}}$ & MIC $^{\mathbf{a}}$ & Clear zone $^{\mathrm{b}}$ \\
\hline Patchouli oil & - & - & - & - & - & - & - & - & - & - \\
\hline Citronella oil & - & - & - & - & - & - & - & - & 5.00 & $12.33 \pm 0.57$ \\
\hline Geramium oil & - & - & - & - & - & - & - & - & - & - \\
\hline Lemongrass oil & - & - & 2.50 & $36.00 \pm 1.00$ & 2.50 & $36.00 \pm 1.00$ & - & - & 2.50 & $28.33 \pm 1.52$ \\
\hline Clove oil & - & - & - & - & - & - & 5.00 & $44.33 \pm 1.15$ & 1.25 & $33.66 \pm 1.52$ \\
\hline Cinnamon oil & 1.25 & $20.00 \pm 0.00$ & 1.25 & $45.33 \pm 1.15$ & 1.25 & $37.66 \pm 0.57$ & - & - & - & - \\
\hline$(+)$ control $(10 \mathrm{mg} / \mathrm{ml})$ & ND & $36.33 \pm 1.15$ & ND & ND & ND & $37.33 \pm 0.57$ & ND & $44.00 \pm 1.00$ & ND & $35.66 \pm 0.57$ \\
\hline$(-)$ control $^{\mathrm{c}}$ & - & - & - & - & - & - & - & - & - & - \\
\hline
\end{tabular}

${ }^{\mathrm{a}}$ MIC (\%), ${ }^{\mathrm{b}}$ Clearing zone of inhibition in terms of (mm), 'DMSO (5\%). -: No inhibition, ND: Not detected, MRSA: Methicillin-resistant Staphylococcus aureus,

DMSO: Dimethyl sulfoxide, MIC: Minimum inhibitory concentration 
Table 2: The minimum bactericidal concentration of essential oils against skin pathogens

\begin{tabular}{|c|c|c|c|c|c|}
\hline \multirow[t]{3}{*}{ Essential oils } & \multicolumn{5}{|l|}{ Microorganisms } \\
\hline & Escherichia coli & MRSA & Staphylococcus aureus & Pseudomonas aeruginosa & Bacillus subtilis \\
\hline & MBC $^{\mathbf{a}}$ & MBC $^{\mathbf{a}}$ & MBC $^{\mathbf{a}}$ & MBC $^{\mathbf{a}}$ & MBC $^{\mathbf{a}}$ \\
\hline Patchouli oil & - & - & - & - & - \\
\hline Citronella oil & - & - & - & - & 5.0 \\
\hline Geranium oil & - & - & - & - & - \\
\hline Lemongrass oil & - & 2.50 & 2.50 & - & 2.50 \\
\hline Cinnamon oil & 1.25 & 1.25 & 1.25 & - & - \\
\hline
\end{tabular}

${ }^{a}$ MBC (\%). MRSA: Methicillin-resistant Staphylococcus aureus, MBC: Minimum bactericidal concentration

\section{REFERENCES}

1. Maibach HI, Aly R. Bacterial infections of the skin. In: Moshella S, Hurley HJ, editors. Dermatology. $3^{\text {rd }}$ ed. Philadelphia, PA: W.B. Saunders; 1992.

2. Peirano G. Multi-resistant enterobacteriaceae new threat to an old prob; expect review of anti infective therapy. Expert Rev Anti Infect Ther 2008;6:657-69.

3. Owlia P, Saderi H, Rasooli I, Sefidkon F. Antimicrobial characteristics of some herbal oils on Pseudomonas aeruginosa with special reference to their chemical compositions. Indian J Pharmacol Res 2009;8:107-14.

4. Mubita C, Syakalima M, Chisenga C, Munyeme M, Bwalya M, Chifumpa G, et al. Antibiograms of faecal Escherichia coli and enterococci species isolated from pastoralist cattle in the interface areas of the Kafue basin in Zambia. Vet Arhiv 2008;78:179-85.

5. Chambers HF, Deleo FR. Waves of resistance: Staphylococcus aureus in the antibiotic era. Nat Rev Microbiol 2009;7:629-41.

6. Karou SD, Nadembega MC, Zeba B Ilboudo DP, Ouermi D, Pignatelli S, et al. Évolution de la résistance de Staphylococcus aureus aux antibiotiques au centre médical Saint Camille De Ouagadougou. Méd Trop 2010;70:241-4.

7. Hossain MT, Siddique MP, Hossain FM, Zinnah MA, Hossain MM, Alam MK, et al. Isolation, identification, toxin profile and antibiogram of Escherichia coli isolated from broilers and layers in Mymensingh district of Bangladesh. Bangl J Vet Med 2008;6:1-5.

8. Arredondo-García JL, Amábile-Cuevas CF. High resistance prevalence towards ampicillin, co-trimoxazole and ciprofloxacin, among uropathogenic Escherichia coli isolates in Mexico city. J Infect Dev Ctries 2008:2:350-3.

9. Kordali S, Kotan R, Mavi A, Cakir A, Ala A, Yildirim A. Determination of the chemical composition and antioxidant activity of the essential oil of Artemisia dracunculus and of the antifungal and antibacterial activities of Turkish Artemisia absinthium, A. dracunculus, Artemisia santonicum, and Artemisia spicigera essential oils. J Agric Food Chem 2005;53:9452-8.

10. World Health Organization. Regional Office for Europe and International Federation of Red Cross and Red Crescent Societies, Infections and Infectious Diseases. A Manual for Nurses and
Midwives in the WHO European Region. Geneva: World Health Organization; 2001.

11. Song A, Wang Y, Liu Y. Study on the chemical constituents of the essential oil of the leaves of Eucalyptus globulus Labill from China. Asian J Tradit Med 2009;4:134-40.

12. Bueno J. Models of evaluation of antimicrobial activity of essential oils in vapour phase: Promising use in healthcare decontamination. Nat Volatiles Esent Oils 2015;2:16-29.

13. Chen H, Tian T, Miao H, Zhao YY. Traditional uses, fermentation, phytochemistry and pharmacology of Phellinus linteus: A review. Fitoterapia 2016;113:6-26.

14. Ács K, Balázs VL, Kocsis B, Bencsik T, Böszörményi A, Horváth G. Antibacterial activity evaluation of selected essential oils in liquid and vapor phase on respiratory tract pathogens. BMC Complement Altern Med 2018;18:227.

15. Bagamboula CF, Uyttendaele M, Debevere J. Antimicrobial effect of spices and herbs on Shigella sonnei and Shigella flexneri. J Food Prot 2003;66:668-73.

16. Bakkali F, Averbeck S, Averbeck D, Zhiri A, Idaomar M. Cytotoxicity and gene induction by some essential oils in the yeast Saccharomyces cerevisiae. Mutat Res 2005;585:1-13.

17. Botelho MA, Nogueira NA, Bastos GM, Fonseca SG, Lemos TL, Matos FJ, et al. Antimicrobial activity of the essential oil from Lippia sidoides, carvacrol and thymol against oral pathogens. Braz J Med Biol Res 2007;40:349-56

18. Castilho PC, Savluchinske-Feio S, Weinhold TS, Gouveia SC. Evaluation of the antimicrobial and antioxidant activities of essential oils, extracts and their main components from oregano from Madeira Island, Portugal. Food Control 2012;23:552-8.

19. Ye CL, Dai DH, Hu WL. Antimicrobial and antioxidant activities of the essential oil from onion (Allium cepa L.). Food Control 2013;30:48-53.

20. Stefanakis MK, Touloupaskis E, Anastospoulos E, Ghanotakis K, Katerinopoulos HE, Makridis P. Antibacterial activity of essential oils from plants of the genus Origanum. Food Control 2013;34:539-46.

21. Ponce AG, Fritz R, Del Valle C, Roura SI. Antimicrobial activity of essential oils on the native microflora of organic Swiss chard. LWT Food Sci Technol 2003;36:679-84 